\title{
Correlations among learning strategy, learning motivation, and speaking ability of students in junior high school
}

\author{
Lismiyati Lismiyati ${ }^{1}$, Baginda Simaibang ${ }^{2}$, Mulyadi Mulyadi ${ }^{2}$ \\ ${ }^{1}$ Sekolah Menengah Pertama Negeri 03 Muaradua \\ ${ }^{2}$ Universitas PGRI Palembang
}

\section{Article Info \\ Article history: \\ Received Jul $11^{\text {th }}, 2021$ \\ Revised Aug $5^{\text {th }}, 2021$ \\ Accepted Aug 30 ${ }^{\text {th }}, 2021$}

\section{Keyword:}

Learning Strategy

Learning Motivation

Speaking Ability

\begin{abstract}
This thesis is concerned with the inquiry on the correlations among learning strategy, learning motivation and the seventh grade students' speaking ability of SMP Negeri 03 Muaradua OKUS. The problem of this study is to investigate the correlations among learning strategy, learning motivation and speaking ability. The total number of the population was 76 students. The sample for this study was 52 students taken through cluster random sampling technique. Data were collected by adopting questionnaire for learning strategy and learning motivation, and a test for speaking ability. Data were analyzed by using r-product moment and multiple regression. Findings show that there are significant correlations among learning strategy, learning motivation, and speaking ability. Conclusions suggest that learning strategy and learning motivation have significant correlations with speaking ability.
\end{abstract}

(C) 2021 The Authors. Published by IICET.

This is an open access article under the CC BY-NC-SA license

(https://creativecommons.org/licenses/by-nc-sa/4.0

\section{Corresponding Author:}

Lismiyati, L.,

Sekolah Menengah Pertama Negeri 03 Muaradua, Indonesia

Email: lismiyati62@gmail.com

\section{Introduction}

Speaking is communication process between at least two people and speaking is a way to express someone's idea. [1] defines speaking as a two-way process between speaker and listener and it involves the productive skill and receptive skill of understanding. Speaking seems to be easy to do, but we do not only speak, we also communicate each other with people by using language.

In speaking skill, the students often find some problems. The problem frequently found is that their first language causes them to get difficulty in using the second language. [2] points out several problems which are faced by poor learners in learning English as a foreign language. First, students can not sustain spoken interaction beyond short segments. Second, students experience frequent communication breakdowns and misunderstandings. Third, students lack of vocabulary that is needed to talk about common utterances. Fourth, students lack of communication strategies. Fifth, students speak slowly and take too long to compose utterances. The last, students cannot participate actively in conversation. Seventh, their spoken English does not sound natural.

In order to become successful in speaking, the students need particular learning strategies. Some students are good and some them are failed. It might be caused by the language learning strategies. In any case, When the students use a greater variety and number of learning strategies, more proficient he/she would be. In parallel to this, After seeing the role of learning strategies in improving students' speaking performance, a 
critical simple question might come to our mind. [3] says that learning strategy plays an important role in effectiveness of helping less successful students improve their speaking performance.

Concerning to students' problem in speaking English, it can be inferred that each learner has certain tendency and capability in using certain learning strategies. Therefore, the use of various learning strategies is influenced by the leaner's family background, experienced, and character. Since learners have their own characteristics, they would exploit different learning strategies that are useful and comfortable to them. This study, therefore, would investigate the learning strategies in speaking used by Junior High School students.

Students' perception of speaking, it is assumed that many Indonesian students have low motivation in learning speaking. Actually, all of students have different motivation in learning speaking. Some of them are highly motivated students. Students with high motivation in learning speaking will push themselves to speak up. They will overcome obstacles which come to them with strong strength from inside. Moreover, motivated students often get best result because motivation will improve their performance. They will become the most successful students. In contrast, low motivated students will have little interest to the subject and tend to have difficulty in learning. In fact, most of students have low motivation in learning speaking.

Low motivated students in learning speaking are caused by many factors. Based on the observation in the school in teaching speaking, here is some factors affects students' motivation. Firstly, the method of teacher in teaching and learning process is not interesting for students. It makes students lazy to learn speaking. Secondly, the situation of environment is not support to speak up, neither inside the classroom nor outside. In the classroom, students have a limited time to learn speaking, so they cannot practice English well in a very little time. While outside the classroom, students are not used to speak English. They prefer to speak in their native language, Indonesian, because almost people around them speak Indonesian. Thirdly, students feel shy and lack of confidence to speak up because they are afraid of making mistakes and being laughed by their friends. Then, students' view about speaking that it is a difficult subject to learn causes them difficult to practice it. They think that many components of language should be mastered to speak English well such as pronunciation, vocabulary, grammar. However, not all low motivated students in learning speaking have low speaking ability. On the other hand, highly motivated students do not always have good speaking ability.

Therefore, the study is conducted to know students' motivation and the strategy in learning speaking ability at the seventh grade of SMP Negeri 03Muaradua, OKU Selatan by the title "Correlations among Learning Strategies, Learning Motivation and Speaking Ability".

Learning strategy has traditionally been included in the taxonomy of individual differences. Yet on a closer look they may not be individual differences factors at all. After all, learning strategy is an aspect of the learning process rather than being learner attributes proper. [3] provided a very broad definition of learning strategy as "the techniques or devices which a learner may use to acquire knowledge". [6] defines learning strategy are specific actions done by learners to make learning easier, faster, more enjoyable, more self-directed, more effective and more transferable to new situations. [7] state learning strategy as learning process in learning which are consciously selected by the learner. [4] defines learning strategy as "mental or behavioral activity related to some specific stage in overall process of language acquisition or language use". In addition, [5] defines learning strategy is used to input to processing, storage, and retrieval, that is to taking in message from others. Based on those definitions, learning strategy is a technique or a certain behavior that is used by students in learning to get knowledge with make learning more quickly, easily, and effectively, so students can achieve the goal of learning.

Motivation is important aspect in every occasion. It is influences someone's work in its process and result. Motivation is something which energizes, give instructions and hold the behavior, motivation make students move, place them to certain aim, and keep them in order to achieve their goal. Motivation is one of the most important substance effective learning. Some experts suggest some definition of motivation. [10] defined Motivation as a theoretical construct used to explain the imitation, direction, intensity, persistency, and quality of behavior, especially goal directed behavior. [11] defined motivation as an internal state that arouses people to action, pushes people in particular behaviors, and keep people engaged in certain activity. [12] defined motivation as an inner, impulse, and emotion or desires that move one to a particular action. [13] Motivation is vital to the success of learning a foreign language.

Based on the definition above, the researcher concludes that learning motivation is a theoretical construct used to explain the process that arouses people to action in particular behaviors, it is important to the success of learning a foreign language.

Speaking is the essential skill among other language skills that must be learned by English students. It is as the major criterion to consider that the English students' competence is good or lack. There are many definitions of speaking from English experts. However, the writer only chooses several definitions which are important to talk about.

According to [8] speaking is a desire and purpose-driven that may involve expressing ideas and opinions; expressing a wishor a desire to do something; negotiation and or solving a particular problem or establishing 
and maintaining social relationship and friendship". Besides Lynne [9]definition, "speaking is the active use of language to express meanings so that peoples can make senses of them". From the definitions above, the writer conclude that speaking is a desire or a wish of person to express ideas, opinions and feelings to others, to negotiate, to solve problems in order to make and to maintain interaction, social relationship, and friendship.The Objective of this study is to investigate "Correlations among Learning Strategy, Learning Motivation and the Seventh Grade Students' Speaking Ability of SMP Negeri 03 Muaradua OKUS".

\section{Method}

This research conducted for the seventh grade students of SMPN 03 Muaradua OKUS, in the academic year of 2020/2021. The reason of choosing this method is that the researcher wants to know the strength of the relation of two or more variables based on correlation coefficient. There are three possible results of a correlational study a positive correlation, a negative correlation, and no correlation. The correlational coefficient is a measure of correlation strength and can range from -1.00 to +1.00 . Perfect positive correlation would result in a score of +1 . Perfect negative correlation would result in -1 [13].

1. Positive correlations: both variables improve or decrease at the same time. A correlation coefficient close to +1.00 indicates a strong positive correlation.

2. Negative correlations: indicates that as the amount of one variable improves the other decreases. A correlation coefficient close to -1.00 indicates a strong negative correlation.

3. No correlations : indicates no relationship between the two variables. A correlation coefficient of indicates no correlation.

The stages that will be taken by the writer in collecting the data: reading literature dealing with the problems, determining the variable and data sources, determining and collecting the instrument of measurement, doing the test and questionnaire, collecting the data, analyzing the data, drawing the conclusion, and writing the report.

\section{Results and Discussions}

\section{Correlation between Learning Strategy and Speaking Ability}

The first hypothesis was tested as follows:

- Ha : There is a significant correlation between learning strategy and speaking ability of the seventh grade students of SMP Negeri 03 Muaradua OKUS.

- Ho : There is not any significant correlationbetween learning strategy and speaking ability of the Seventh grade students of SMP Negeri 03 Muaradua OKUS.

To calculate the regression among three variables, the researcher used r-Product Moment. The result of the calculation is presented in Table below.

Table 1. Correlation between Learning Strategy and Speaking Ability Correlations

\begin{tabular}{|ll|r|r|}
\hline & & Learning Startegy & Speaking Ability \\
\hline Learning & Pearson Correlation & 1 & 893 \\
Startegy & Sig. (2-tailed) & & .019 \\
& $\mathrm{~N}$ & 52 & 52 \\
Speaking & Pearson Correlation & 893 & 1 \\
Ability & Sig. (2-tailed) & .019 & 52 \\
\hline
\end{tabular}

Table 1 shows that p-value is 0,019 . This value is lower than 0,05 . This is significant. So Ha is accepted while Ho is rejected. Therefore, there is a significant correlation between learning strategy and speaking ability of the seventh grade students of SMPNegeri 03 Muaradua OKUS.

\section{Correlation between Learning Motivation and Speaking Ability}

The second hypothesis was tested as follows: 
- Ha : There is a significant correlation betweenlearning motivation and speaking ability of the seventh grade students of SMP Negeri 03 Muaradua OKUS.

- Ho : There is not any significant correlation between learning motivation and speaking ability of the Seventh grade students of SMP Negeri 03 Muaradua OKUS.

To calculate the regression among three variables, the researcher used r-Product Moment. The result of the calculation is presented in Table below.

Table 2. Correlation between Learning Motivation and Speaking Ability

\section{Correlations}

\begin{tabular}{|ll|r|r|}
\hline & & Learning Motivation & Speaking Ability \\
\hline \multirow{3}{*}{ Learning Motivation } & Pearson Correlation & 1 & $.432^{* *}$ \\
& Sig. (2-tailed) & & .001 \\
& $\mathrm{~N}$ & 52 & 52 \\
& Pearson Correlation & $.432^{* *}$ & 1 \\
Speaking Ability & Sig. (2-tailed) & .001 & 52 \\
& $\mathrm{~N}$ & 52 & 52 \\
\hline
\end{tabular}

Table 2 shows that p-value is 0,001 . This value is lower than 0,05 . This is significant. So $\mathrm{Ha}$ is accepted while Ho is rejected. Therefore, there is a significant correlation between learning motivation and speaking ability of the Seventh grade students of SMPNegeri 03 Muaradua OKUS.

\section{Correlation between Learning Strategy and Learning Motivation}

The third hypothesis was tested as follows:

- $\mathrm{Ha}$ : There is a significant correlation between learning strategy and learning motivation of the seventh grade students of SMP Negeri 03 Muaradua OKUS.

- Ho : There is not any significant correlation between learning strategy and learning motivation of the seventh grade students of SMP Negeri 03 Muaradua OKUS.

To calculate the regression among three variables, the researcher used r-Product Moment. The result of the calculation is presented in Table below.

Table 3. Correlation between Learning Strategy and Learning Motivation

\section{Correlations}

\begin{tabular}{|c|c|c|c|}
\hline & & Learning Startegy & Learning Motivation \\
\hline \multirow{3}{*}{ Learning Startegy } & Pearson Correlation & 1 & .166 \\
\hline & Sig. (2-tailed) & & .024 \\
\hline & & 52 & 52 \\
\hline \multirow{3}{*}{ Learning Motivation } & Pearson Correlation & .166 & 1 \\
\hline & Sig. (2-tailed) & .024 & \\
\hline & $\mathrm{N}$ & 52 & 52 \\
\hline
\end{tabular}

Table 3 shows that p-value is 0,024 . This value is lower than 0,05 . This is significant. So Ha is accepted while Ho is rejected. Therefore there is a significant correlation between learning strategy and learning motivation of the Seventh grade students of SMP Negeri 03 Muaradua OKUS.

Correlations among Learning strategy, Learning Motivation and Speaking Ability

The fourth hypothesis was tested as follows: 
- Ha :There are significant correlations among learning strategy, learning motivation, and speaking ability of the seventh grade students of SMP Negeri 03 Muaradua OKUS.

- Ho :There are not any significant correlations among learning strategy, learning motivation, and speaking ability of the seventh grade students of SMP Negeri 03 Muaradua OKUS.

To calculate the regression among three variables, the researcher used Multiple Regression. The result of the calculation is presented in Table below.

Table 4. Correlations among Learning Strategy, Learning Motivation and Speaking Ability ANOVA $^{\mathrm{a}}$

\begin{tabular}{|c|c|c|c|c|c|c|}
\hline \multicolumn{2}{|c|}{ Model } & Sum of Squares & $\mathrm{df}$ & Mean Square & $\mathrm{F}$ & Sig. \\
\hline \multirow{3}{*}{1} & Regression & 14.754 & 2 & 7.377 & .913 & $.004^{\mathrm{b}}$ \\
\hline & Residual & 395.939 & 49 & 8.080 & & \\
\hline & Total & 410.692 & 51 & & & \\
\hline
\end{tabular}

a. Dependent Variable: Speaking Ability

b. Predictors: (Constant), Learning Motivation, Learning Strategy

Table 4 shows that p-value is 0,004 . This value is lower than 0,05 . This is significant. So Ha is accepted while Ho is rejected. Therefore, there are significant correlations among learning strategy, learning motivation, and speaking ability of the seventh grade students of SMP Negeri 03 Muaradua OKUS.

\section{Discussions}

This research was conducted for the eleventh grade students of SMP Negeri 03 Muaradua. This research has three types of data. They are learning strategy, learning motivation, and speaking ability. The data of learning strategy were collected by using questionnaire which administrated on October 9th-, 2020, the data of learning motivation were collected by using questionnaire which administrated on October 9th, 2020 and the data of speaking ability were collected by using an oral test through transactional conversation administrated on November 3rd , 2020. In scoring students' speaking ability, the researcher assisted by a rater. She is Mrs. TemyRosalinda,S.Pd.She is a English teacher of SMP Negeri 03 Muaradua OKUS.

First, finding from hypothesis testing no.1 proved there is significant correlation between learning strategy (X1) and speaking ability (Y). The significant level was $0,019<0,05$ consequently Ho is rejected. It means that there is a significant correlation between learning strategy and speaking ability of the seventh grade students of SMP Negeri 03 Muaradua. It means that the contribution of students' learning strategy to students' speaking is influenced by other factors. Learning strategy is a personal factor that plays a supportive role in achievement foreign language learning. This is supported by the result of data calculation. It shows that there is a correlation between learning strategy and speaking ability.

Second, finding from hypothesis testing no.2 proved there is significant correlation between learning motivation (X2) and speaking ability (Y). The significant level was $0,001>0,05$ consequently Ha is accepted. It means that there is a significant correlation between learning motivation and speaking ability of the seventh grade students of SMP Negeri 03 Muaradua. It means that the contribution of students' learning motivation to students' speaking ability is influenced by other factors. The students who have high motivation will make an effort to follow the learning process intensively, and they learn the lesson as well as possible not only in the school but also out of the school. They are motivated to enrich their vocabulary and to practice their speaking ability. Moreover, motivated students usually feel enjoyable in their learning. It makes them easier to speak up confidently wherever they are although English is a foreign language. This is supported by the result of data calculation. It shows that there is a correlation between learning motivation and speaking ability.

Third, finding from hypothesis testing no. 3 proved there is a significant correlation between learning strategy (X1) and learning motivation (X2). The significant level was 0,024 $<0,05$ consequently Ho is rejected. It means that there is a significant correlation between learning strategy and learning motivation of the seventh grade students of SMP Negeri 03 Muaradua. Learning strategy is important, If people have strategy, their knowledge will be wider, they are going to get so much information from the things that they read, and they get something. In other words, we can conclude that learning strategy is important in our life.Therefore, in the process of learning, motivation can be said as an inner drive to achieve learning activity so the purpose of the subject learning can be maintained in the educational environment. If the students have low of their learning strategy, they will not be motivated in learning. It means they will have low learning motivation. 
Fourth, finding from hypothesis testing no.4 proved there are significant correlations among learning strategy, learning motivation, and speaking ability. The significant change level was $0,004>0,05$ consequently $\mathrm{Ha}$ is accepted. It means that there are significant correlations among learning strategies, learning motivation, and speaking ability of the seventh grade students of SMP Negeri 03 Muaradua. It means there are correlations among learning strategy, learning motivation and speaking ability simultaneously. $r_{x l y}=0,004$ means that the contribution of students' learning strategy and learning motivation to students' speaking ability is is influenced by other factors.

\section{Conclusions}

In line with the findings in the previous chapter, the following conclusions can be drawn as follows:

This research deals to answer the questions:1)There is a significant correlation between the seventh grade students' learning strategy and speaking ability of SMP Negeri 03Muaradua, OKU Selatan.2)There is a significant correlation between the seventh grade students' learning motivation and speakaing ability of SMP Negeri 03Muaradua, OKU Selatan.3)There is a significant correlation between the seventh grade students' learning strategy and learning motivation of SMP Negeri 03 Muaradua, OKU Selatan. 4)There are significant correlations among learning strategy, learning motivation and speaking ability of the seventh grade of SMP Negeri 03 Muaradua, OKU Selatan.

\section{References}

Byrne, D.1984. Teaching Oral English. Great Britarian: Oxford University Press.

Richards, J. C. 2002. Methodology in Language Teaching. Cambridge: Cambridge University Press.

Chamot, A. U. (2004). Learning Strategies of Students of Less Commonly Taught Languages. San Diego, CA: The American Educational Research Association.

Ellis, R. 1994. The Study of Second Language Acquisition. Oxford: Oxford University Press.

Brown, HD. 2000. Principles of Language Learning and Teaching (4thed.). San Fransisco: Addison Wesley Longman, Inc.

Oxford, R. (1990). Language Learning Strategies: What Every Teacher Should Know. Rowley, Mass: Newbury House.

Dörnyei, Z. (1998). "Motivation in Action: A Process Model of L2 Motivation". Working Papers in Applied Linguistics, 4 .

McDonough, Jo and Christopher Shaw.Materials and Method in ELT: A Teacher's Guide. Cambridge: Blackwell Publisher, 1993.

Cameron, Lynne. Teaching Language To Young Learners. Cambridge: Cambridge University Press, 2001.

Maehr, M., \& Meyer, H. (1997).Understanding motivation and schooling: Where we've been, where we are, and where we need to go. Educational PsychologyReview 9, 371-409.

Elliot, N. 2000.Educational Psychology. Third Edition. USA: McGraw-Hill Companies, Inc

Brown, H.D. (2001). Teaching by principles: An interactive approach to language pedagogy . White Plains. NY: Longman.

Nunan, D. (1995). Language Teaching Methodology a Textbook for Teachers, NY: Phoenix Ltd. 